\title{
[Regular Paper] \\ Solution XAS Analysis of Various (Imido)vanadium(V) Dichloride Complexes Containing Monodentate Anionic Ancillary Donor Ligands: Effect of Aluminium Cocatalyst in Ethylene/Norbornene (Co)polymerization
}

\author{
Kotohiro NomURA $^{\dagger 1) *}$, Ken Tsutsumi ${ }^{\dagger 1}$, Go NAGAI $^{\dagger 1)}$, Takuya OMIYA ${ }^{\dagger 1)}$, \\ Toshiaki InA $^{\dagger 2)}$, Seiji YAMAZOE ${ }^{\dagger 1) *}$, and Takato MitsudOME ${ }^{\dagger 3) *}$ \\ †1) Dept. of Chemistry, Tokyo Metropolitan University, 1-1 Minami Osawa, Hachioji, Tokyo 192-0397, JAPAN \\ ${ }^{\dagger 2)}$ Japan Synchrotron Radiation Research Institute (JASRI, SPring-8), Sayo, Hyogo 679-5198, JAPAN \\ ${ }^{\dagger 3}$ Dept. of Materials Engineering Science, Osaka University, 1-3 Machikaneyama, Toyonaka, Osaka 560-8531, JAPAN
}

(Received March 28, 2018)

\begin{abstract}
Effects of ligand and ligand substituents in a series of (imido)vanadium $(\mathrm{V})$ complexes containing monodentate anionic ancillary donor ligands of the type, $\mathrm{V}(\mathrm{NAr}) \mathrm{Cl}_{2}(\mathrm{~L})\left[\mathrm{Ar}=2,6-\mathrm{Me}_{2} \mathrm{C}_{6} \mathrm{H}_{3} ; \mathrm{L}=\mathrm{OAr}, \mathrm{O}-2,6-\mathrm{Ph}_{2} \mathrm{C}_{6} \mathrm{H}_{3}, \mathrm{~N}=\right.$ $\mathrm{C}^{t} \mathrm{Bu}_{2}, 1,3-{ }^{t} \mathrm{Bu}_{2}(\mathrm{CHN})_{2} \mathrm{C}=\mathrm{N}$, WCA-NHC (anionic $N$-heterocyclic carbenes with a weakly coordinating borate moiety)] and $\mathrm{V}(\mathrm{NAd}) \mathrm{Cl}_{2}(\mathrm{OAr})(\mathrm{Ad}=1$-adamantyl), were explored by the solution $\mathrm{V}$ K-edge XANES (pre-edge and edge region) spectra. No significant differences in the pre-edge (and the edge) peaks were observed between these complexes which fold a distorted 4 coordinate tetrahedral geometry around vanadium; the shoulder-edge peaks ascribed to the presence of $\mathrm{V}-\mathrm{Cl}$ bonds were also observed in all cases. No significant spectral changes were observed when the phenoxy analogues (exhibiting catalytic activities for ethylene/norbornene copolymerization) were treated with MAO, and even addition of norbornene, suggesting preservation of the oxidation state. Remarkable changes in the XANES spectrum (decrease in the intensity of the pre-edge peak and low-energy shift of the edge region) were observed after addition of $\mathrm{Al}^{i} \mathrm{Bu}_{3}$ toward $\mathrm{V}(\mathrm{NAr}) \mathrm{Cl}_{2}$ (WCA-NHC), and no notable changes were observed upon further addition of $\mathrm{Al}^{i} \mathrm{Bu}_{3}$ and norbornene; these results suggest that the formed species, presumably vanadium(III), act directly as the active species in this catalysis.
\end{abstract}

\author{
Keywords \\ Vanadium complex catalyst, XANES spectra, Oxidation state, Ethylene copolymerization, \\ Aluminium cocatalyst, Norbornene
}

\section{Introduction}

Polyolefins [such as high density polyethylene (HDPE), linear low density polyethylene (LLDPE), and polypropylene (PP)] are important synthetic polymers generally produced by transition metal catalyzed olefin polymerization. Design of more effective molecular catalysts for precise polymerization is very important for the synthesis of new polymers as well as development of more efficient processes ${ }^{1) \sim 10)}$. Vanadium complex catalysts offer unique characteristics (high reactivity toward olefins) as reported by the classical Ziegler-type vanadium catalyst systems $\left[\mathrm{VOCl}_{3}\right.$ and $\mathrm{Et}_{2} \mathrm{AlCl}, \mathrm{EtAlCl}{ }_{2},{ }^{n} \mathrm{BuLi}$ etc. $]^{7), 11) \sim 14)}$. (Imido)-

This paper was presented at the Tottori Convention of JPI (46th Petroleum-Petrochemical Symposium of Jpn. Petrol. Inst.), Tottori, Japan, Nov. 16-17, 2017.

DOI: doi.org/10.1627/jpi.61.282

* To whom correspondence should be addressed.

* E-mail: ktnomura@tmu.ac.jp (KT), yamazoe@tmu.ac.jp (SY), mitsudom@cheng.es.osaka-u.ac.jp (TM)
vanadium(V) complexes containing monodentate anionic donor ligands $(\mathrm{L})$ of the type, $\mathrm{V}(\mathrm{NAr}) \mathrm{Cl}_{2}(\mathrm{~L})[\mathrm{L}$ $=\operatorname{aryloxo}(\mathbf{1 a}, \mathbf{b})^{15) \sim 18)}$, ketimide $(\mathbf{2})^{19), 20)}$, imidazolin2-iminato (3) ${ }^{21)}$ etc., Scheme 1], are known to exhibit remarkable catalytic activities for the ethylene polymerization $^{15) \sim 21)}$ and the copolymerization with norbornene $(\mathrm{NBE})^{16) \sim 18), 21)}$. Moreover, we recently reported that the (arylimido)vanadium(V) complexes containing anionic $N$-heterocyclic carbenes with a weakly coordinating borate $\left[\mathrm{B}\left(\mathrm{C}_{6} \mathrm{~F}_{5}\right)_{3}\right]$ moiety $(\mathrm{WCA}-\mathrm{NHC})^{22), 23)}$ of the type, $\mathrm{V}(\mathrm{NAr}) \mathrm{Cl}_{2}$ (WCA-NHC) $[4, \mathrm{NHC}=1,3-$ bis(2,6-dimethylphenyl)-imidazolin-2-ylidene, Scheme 1], exhibited remarkably high catalytic activity for ethylene polymerization in the presence of $\mathrm{Al}^{i} \mathrm{Bu}_{3}{ }^{24}$, which has been considered as an ineffective Al cocatalyst in the metal catalyzed polymerization ${ }^{1) \sim 21)}$. The activity of $\mathbf{4}$ in the presence of $\mathrm{Al}^{i} \mathrm{Bu}_{3}$ for ethylene polymerization was apparently higher than that of $\mathbf{4}$ in the presence of methylaluminoxane (MAO), $\mathrm{Et}_{2} \mathrm{AlCl}$ cocatalyst $^{24)} ; \mathbf{4}$ also efficiently copolymerized ethylene with NBE in the presence of $\mathrm{Al}^{i} \mathrm{Bu}_{3}$ (Scheme 1) ${ }^{25}$. 
${ }^{51} \mathrm{~V}$ nuclear magnetic resonance (NMR) and electron spin resonance (ESR) spectra, and V K-edge X-ray absorption near edge structure (XANES) spectra of the catalyst solution demonstrated that the observed different performances in the presence of $\mathrm{MAO}$ and $\mathrm{Al}^{i} \mathrm{Bu}_{3}$ are due to formation of different catalytically active species with different oxidation states ${ }^{25}$.

Synchrotron X-ray absorption spectroscopy (XAS) is a powerful tool for obtaining structural information about the oxidation state by analysis of pre-edge and edge peaks in XANES analysis, and the coordination atoms around the metal center by FT-extended X-ray absorption fine structure (EXAFS) analysis. XAS is recognized as one of the most effective methods for the study of heterogeneous catalysis ${ }^{26) \sim 34)}$. However, reported examples of solution XANES spectra, especially of homogeneous (molecular) catalysis have been limited ${ }^{25), 34) ~ 39)}$. Solution XANES analysis can provide information about both oxidation state and structural information in-situ ${ }^{25), 34), 36) ~ 39)}$, which cannot be obtained by X-ray crystallographic analysis, and can identify both paramagnetic and diamagnetic species (as analyzed by NMR and/or ESR spectra $)^{40) \sim 43)}$, even "NMR and ESR silent" species ${ }^{34)}$.

Solution XANES spectra of vanadium complexes $^{25), 34), 38), 39)}$ display certain unique characteristics compared to those in the solid state, this study thus describes the XANES spectra of a series of 4 coordinate (imido)vanadium(V) dichloride complexes containing monodentate anionic ancillary donor ligands (shown in Scheme 1) to explore the effects of the ligand and the ligand substituents to on the spectra (pre-edge and edge peak $)^{44)}$, as well as the spectra of the catalyst solutions with the addition of different $\mathrm{Al}$ cocatalysts (in the presence of monomers, norbornene $)^{15) \sim 20), 24), 25)}$ to obtain direct information concerning oxidation of the catalytically active species.

\section{Results and Discussion}

\section{1. Solution XANES Spectra of (Imido)- vanadium(V) Dichloride Complexes Containing Monodentate Anionic Donor Ligands}

Figure 1 shows the solution-phase V K-edge XANES spectra (in toluene at $25{ }^{\circ} \mathrm{C}, 5.46 \mathrm{keV}$, obtained using synchrotron radiation at SPring-8, BL01B1 beamline) for a) $\mathrm{V}(\mathrm{NAr}) \mathrm{Cl}_{2}\left(\mathrm{O}-2,6-\mathrm{R}_{2} \mathrm{C}_{6} \mathrm{H}_{3}\right)[\mathrm{R}=\mathrm{Me}(\mathbf{1 a}), \mathrm{Ph}$ (1b), $\left.\mathrm{Ar}=2,6-\mathrm{Me}_{2} \mathrm{C}_{6} \mathrm{H}_{3}\right]$ and $\mathrm{V}(\mathrm{NAd}) \mathrm{Cl}_{2}(\mathrm{OAr})(\mathbf{1 c}, \mathrm{Ad}$ $=1$-adamantyl $)$, and b) $\mathrm{V}(\mathrm{NAr}) \mathrm{Cl}_{2}(\mathrm{~L})[\mathrm{L}=\mathrm{OAr}(\mathbf{1 a})$, $\mathrm{O}-2,6-\mathrm{Ph}_{2} \mathrm{C}_{6} \mathrm{H}_{3}(\mathbf{1 b}), \mathrm{N}=\mathrm{C}^{t} \mathrm{Bu}_{2}(\mathbf{2}), 1,3-{ }^{t} \mathrm{Bu}_{2}(\mathrm{CHN})_{2} \mathrm{C}$ $=\mathrm{N}(3), \mathrm{WCA}-\mathrm{NHC}(\mathbf{4})]$. In the XANES spectra, the valence is often determined by the position of the $\mathrm{K}$ and/or $\mathrm{L}_{1}$-edges, and the local symmetry is inferred by the pre-edge peak area of the $\mathrm{K}$ - or $\mathrm{L}_{1}$-edge spectra, which show $\mathrm{s} \rightarrow \mathrm{d}$ transitions ${ }^{45) \sim 48)}$. Moreover, the

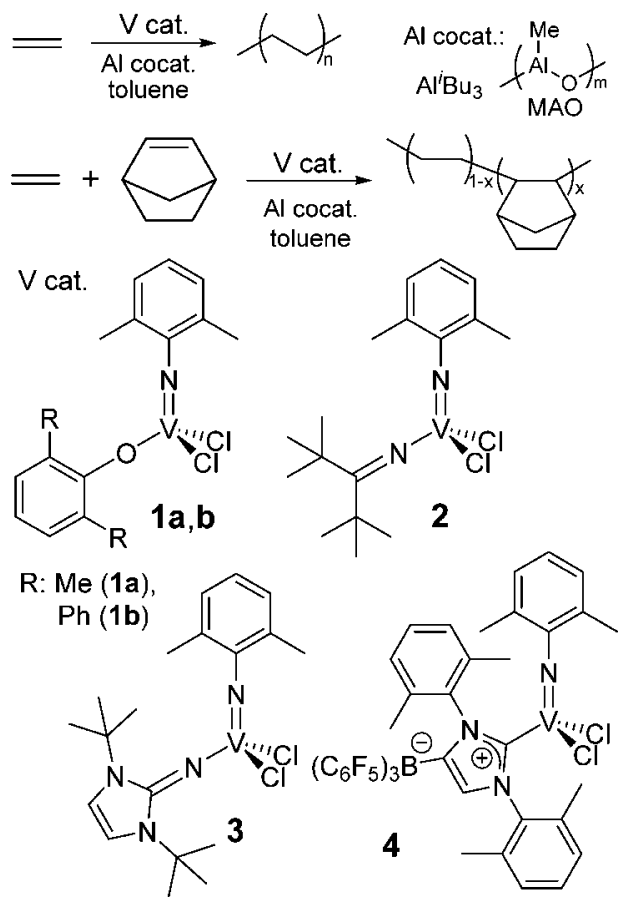

Shceme 1 Ethylene (Co)polymerization Using V(NAr)Cl ${ }_{2}(\mathrm{~L})$ (1-4)Al Cocatalysts

characteristics of pre-edge peaks in K-edge XANES spectra of $3 \mathrm{~d}$ transition metals are known to be affected by the selection rule, coordination number, number of d-electrons, and coordination sphere symmetry. Transition of a $1 \mathrm{~s}$ electron to $3 \mathrm{~d}$ orbital gives weak preedge peaks due to the electric quadrupole transition for any symmetries. An intense pre-edge peak is assigned to an electric dipole transition to p-character in the d-p hybridized orbital. Mixing of a metal $4 p$ orbital with the $3 \mathrm{~d}$ orbital strongly depends on the coordination symmetry, and the degree of which is predictable with group theory. Therefore, centered atoms with tetrahedral $\left(T_{\mathrm{d}}\right)$ symmetry display large pre-edge peak areas in $\mathrm{K}$ - and $\mathrm{L}_{1}$-edge XANES spectra.

XANES spectra for $\mathrm{V}(\mathrm{NAr}) \mathrm{Cl}_{2}\left(\mathrm{O}-2,6-\mathrm{R}_{2} \mathrm{C}_{6} \mathrm{H}_{3}\right)[\mathrm{R}=$ $\left.\mathrm{Me}(\mathbf{1 a}), \mathrm{Ph}(\mathbf{1 b}), \mathrm{Ar}=2,6-\mathrm{Me}_{2} \mathrm{C}_{6} \mathrm{H}_{3}\right]$ and V(NAd) $\mathrm{Cl}_{2}$ (OAr) (1c, $\mathrm{Ad}=1$-adamantyl) complexes in Fig. 1a) showed pre-edge peak (and a shoulder peak) [5466.8 (and 5465.3) eV (1a), 5467.4 (and 5465.2) eV (1b), 5467.2 (and 5465.8) eV (1c), respectively] similar to those in $\mathrm{V}(\mathrm{NAr}) \mathrm{Cl}_{3}[5466.8 \text { (and 5465.0) e V }]^{25)}$, $\mathrm{V}(\mathrm{NAd}) \mathrm{Cl}_{3}[5467.1 \text { (and 5465.6) } \mathrm{eV}]^{38}$ ). The obtained spectrum was highly reproducible as demonstrated for 1a. These pre-edge peaks are considered to show a transition from $1 \mathrm{~s}$ to $3 \mathrm{~d}+4 \mathrm{p}^{45) \sim 48)}$, although limited examples of solution V K-edge XANES spectra through synchrotron radiation are available. Moreover, XANES spectra of these complexes (1a-1c) showed a shoulder-edge peak $(5478.2,5478.2,5478.6 \mathrm{eV}$, respectively), located relatively close to those in $\mathrm{V}(\mathrm{NAr}) \mathrm{Cl}_{3}$, 

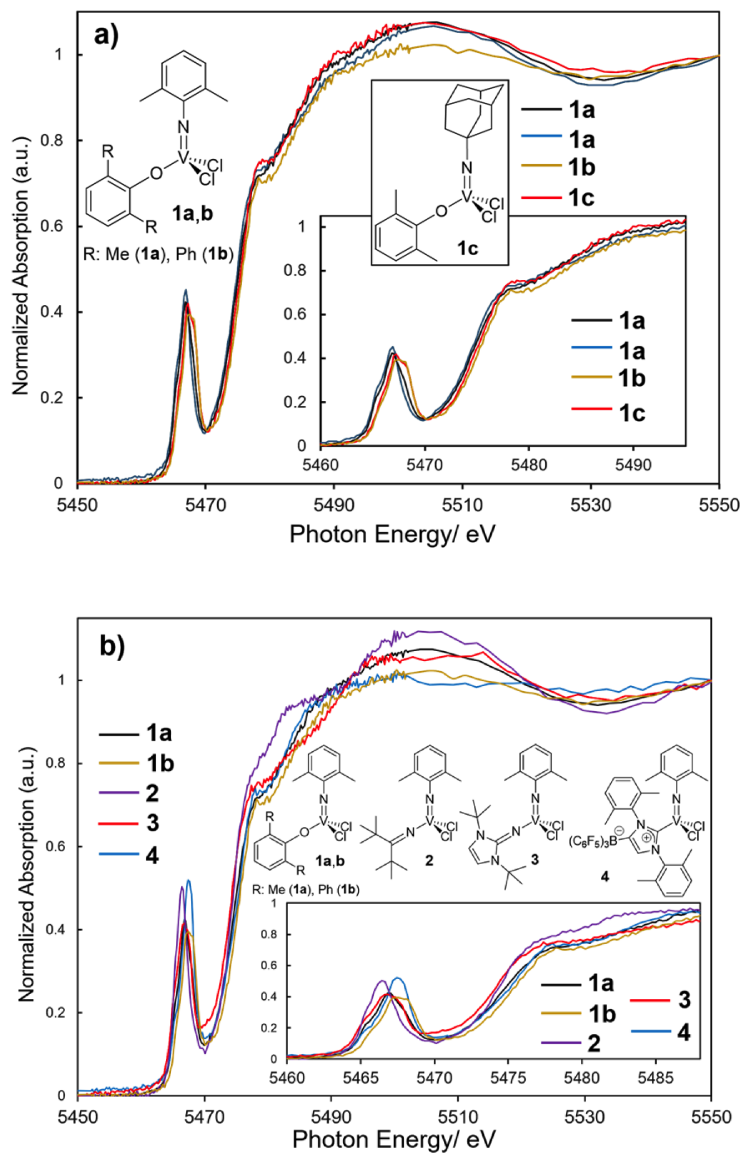

Fig. 1 Solution-phase $\mathrm{V}$ K-edge XANES Spectra (in toluene at $25{ }^{\circ} \mathrm{C}$ ) for a) $\mathrm{V}(\mathrm{NAr}) \mathrm{Cl}_{2}\left(\mathrm{O}-2,6-\mathrm{R}_{2} \mathrm{C}_{6} \mathrm{H}_{3}\right)[\mathrm{R}=\mathrm{Me}(\mathbf{1 a}), \mathrm{Ph}$ (1b), $\left.\mathrm{Ar}=2,6-\mathrm{Me}_{2} \mathrm{C}_{6} \mathrm{H}_{3}\right]$ and $\mathrm{V}(\mathrm{NAd}) \mathrm{Cl}_{2}\left(\mathrm{O}-2,6-\mathrm{Me}_{2} \mathrm{C}_{6} \mathrm{H}_{3}\right)$ (1c, $\mathrm{Ad}=1$-adamantyl), and b) $\mathrm{V}(\mathrm{NAr}) \mathrm{Cl}_{2}(\mathrm{~L})[\mathrm{L}=\mathrm{OAr}(\mathbf{1 a})$ $\mathrm{O}-2,6-\mathrm{Ph}_{2} \mathrm{C}_{6} \mathrm{H}_{3}(\mathbf{1 b}), \mathrm{N}=\mathrm{C}^{t} \mathrm{Bu}_{2}(\mathbf{2}), \mathrm{N}=\mathrm{C}\left({ }^{t} \mathrm{BuNCH}\right)_{2}(\mathbf{3})$, WCA-NHC (4)] (Two spectra of 1a in Fig. 1a) are independent runs with different beam times for checking the reproducibility.)

$\mathrm{V}(\mathrm{NAd}) \mathrm{Cl}_{3}(5477.6,5476.7 \mathrm{eV}$, respectively). The shoulder-edge peak was ascribed to the $\mathrm{V}-\mathrm{Cl}$ bond confirmed previously ${ }^{34), 38)}$. Consequently, the substituent in both the imido and the phenoxy ligands did not cause significant differences in the spectra.

XANES spectra of the dichloride complexes containing ketimide ligand, $\mathrm{V}(\mathrm{NAr}) \mathrm{Cl}_{2}\left(\mathrm{~N}=\mathrm{C}^{t} \mathrm{Bu}_{2}\right)(2)^{34)}$, imidazolin-2-iminato ligand, $\mathrm{V}(\mathrm{NAr}) \mathrm{Cl}_{2}\left[1,3-{ }^{t} \mathrm{Bu}_{2}(\mathrm{CHN})_{2} \mathrm{C}\right.$ $=\mathrm{N}](3)$, and WCA-NHC ligand, $\mathrm{V}(\mathrm{NAr}) \mathrm{Cl}_{2}$ [WCANHC] (4) in Fig. 1b) showed pre-edge peak (and shoulder peak) [at 5466.4, 5466.9, 5467.4 eV (and $5465.1 \mathrm{eV})$, respectively]. The peaks for $4(5467.4 \mathrm{eV})$ and 1b, 1c (5467.4, 5467.2 eV, respectively) were slightly different (high energy shifted) from that for $\mathbf{2}$ $(5466.4 \mathrm{eV})$; the peaks for $\mathbf{1 a}(5466.8 \mathrm{eV})$ and $\mathbf{3}$ $(5466.9 \mathrm{eV})$ are within the range of $5466.4-5467.4 \mathrm{eV}$. This order $(\mathbf{2}<\mathbf{1 a}, \mathbf{3}<\mathbf{1 b}, \mathbf{1 c}, \mathbf{4})$ does not agree with the observed chemical shift in the ${ }^{51} \mathrm{~V}$ NMR spectra (4 $\ll 2<3)^{20) \sim 22)}$. This observed difference is difficult

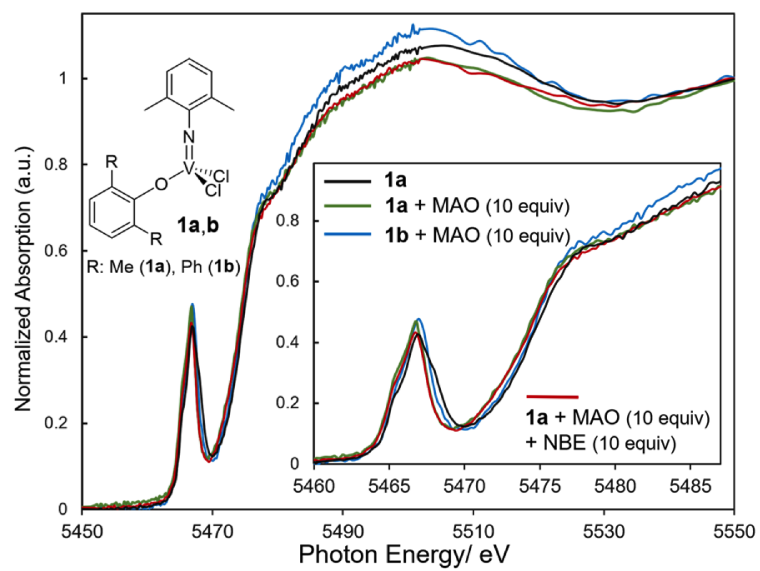

Fig. 2 Solution-phase V K-edge XANES Spectra (in toluene at $25^{\circ} \mathrm{C}$ ) for $\mathrm{V}(\mathrm{NAr}) \mathrm{Cl}_{2}\left(\mathrm{O}-2,6-\mathrm{R}_{2} \mathrm{C}_{6} \mathrm{H}_{3}\right)[\mathrm{R}=\mathrm{Me}(\mathbf{1 a}), \mathrm{Ph}(\mathbf{1 b})$, $\left.\mathrm{Ar}=2,6-\mathrm{Me}_{2} \mathrm{C}_{6} \mathrm{H}_{3}\right]$ after Addition of MAO (10.0 equiv.)

to explain at present. As observed in 1a-c and the trichloride analogues $\left[\mathrm{V}(\mathrm{NAr}) \mathrm{Cl}_{3}, \mathrm{~V}(\mathrm{NAd}) \mathrm{Cl}_{3}\right]$, complexes 2-4 showed a shoulder-edge peak (5478.2, 5478.1, $5477.7 \mathrm{eV}$, respectively) were assumed and defined as ascribed to the $\mathrm{V}-\mathrm{Cl}$ bond $^{34), 38)}$. These results clearly indicate that basic spectral characteristics (pre-edge, shoulder-edge, and edge peaks) are maintained among these complexes (1a-c, 2-4), which all have distorted 4-coordinate tetrahedral geometry around vanadium.

2. 2. Analysis of Catalyst Solution Consisting of V(NAr) $\mathrm{Cl}_{2}\left(\mathrm{O}-2,6-\mathrm{R}_{2} \mathrm{C}_{6} \mathrm{H}_{3}\right)[\mathrm{R}=\mathrm{Me}(1 \mathrm{a}), \mathbf{P h}$ (1b)], V(NAr) $\mathrm{Cl}_{2}$ ( WCA - NHC) (4) and Aluminium Cocatalysts by XANES Spectroscopy

We reported previously that $\mathrm{V}(\mathrm{NAr}) \mathrm{Cl}_{2}(\mathrm{O}-2,6-$ $\left.\mathrm{R}_{2} \mathrm{C}_{6} \mathrm{H}_{3}\right)[\mathrm{R}=\mathrm{Me}(\mathbf{1 a}), \mathrm{Ph}(\mathbf{1 b})]$ showed moderate catalytic activity for ethylene polymerization (2930, $1090 \mathrm{~kg}-\mathrm{PE} / \mathrm{mol}-\mathrm{V} \mathrm{h}$, ethylene $8 \mathrm{~atm}$ in toluene at $25{ }^{\circ} \mathrm{C}$ ) in the presence of MAO cocatalyst ${ }^{16)}$. These complexes also showed efficient norbornene (NBE) incorporation in the ethylene/NBE copolymerization resulting in high molecular weight copolymers with uniform molecular weight distributions as well as compositions ${ }^{16)}$.

Figure 2 shows the XANES spectra in toluene solution for complexes 1a,b after addition of MAO and addition of MAO and NBE. The pre-edge peak in 1a $(5466.8 \mathrm{eV})$ did not change with addition of either 10 equiv. of MAO (5466.8 eV), or of MAO and NBE $(5466.7 \mathrm{eV})$. Moreover, no significant change in the pre-edge peak in $\mathbf{1 b}(5467.4 \mathrm{eV})$ was observed with addition of 10 equiv. of MAO $(5467.0 \mathrm{eV})$. These results clearly suggest that both the oxidation state and the basic structure (ligand frame work, especially both imido and aryloxo) were maintained after addition of MAO (suggesting that cationic vanadium(V) alkyl species is the active species), as previously demonstrated 


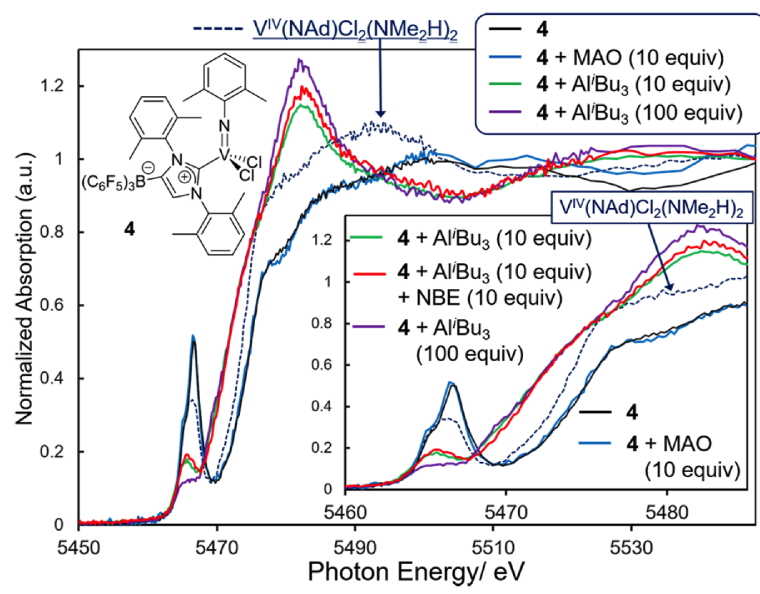

Fig. 3 Solution-phase V K-edge XANES Spectra (in toluene at $25^{\circ} \mathrm{C}$ ) for $\mathrm{V}\left(\mathrm{N}-2,6-\mathrm{Me}_{2} \mathrm{C}_{6} \mathrm{H}_{3}\right) \mathrm{Cl}_{2}$ (WCA-NHC) (4) after Addition of $\mathrm{MAO}$ (10.0 equiv.) or $\mathrm{Al}^{i} \mathrm{Bu}_{3}$ (10.0 equiv. or 100 equiv.) and/or Norbornene (NBE, 10.0 equiv.), and the Spectrum for $\mathrm{V}(\mathrm{NAd}) \mathrm{Cl}_{3}\left(\mathrm{NMe}_{2} \mathrm{H}\right)_{2}$ is Also Shown for Comparison $^{25), 39)}$

in the ethylene dimerization using (imido)vanadium complexes containing 2-anilido(methyl)pyridine ligands, $\mathrm{V}(\mathrm{NAd}) \mathrm{X}_{2}\left[2-\mathrm{ArNCH}_{2}\left(\mathrm{C}_{5} \mathrm{H}_{4} \mathrm{~N}\right)\right](\mathrm{X}=\mathrm{Cl}, \mathrm{Me})^{38)}$, and in ethylene polymerization using $\mathrm{V}(\mathrm{NAr}) \mathrm{Cl}_{2}$ (WCANHC) $(4)^{25)}$, as also shown below for comparison.

Figure 3 shows solution phase XANES spectra for $\mathrm{V}(\mathrm{NAr}) \mathrm{Cl}_{2}$ (WCA-NHC) (4) after addition of $\mathrm{Al}^{i} \mathrm{Bu}_{3}$ and NBE. Complex $\mathbf{4}$ exhibited high catalytic activity for ethylene polymerization in the presence of $\mathrm{Al}$ cocatalysts ${ }^{24)}$, and the activity with addition of $\mathrm{Al}^{i} \mathrm{Bu}_{3}$ (considered as an ineffective Al cocatalyst for olefin polymerization) was higher than that in the presence of $\mathrm{MAO}^{24)}$; the catalyst system (4 and $\left.\mathrm{Al}^{i} \mathrm{Bu}_{3}\right)$ was also effective for ethylene/NBE copolymerization ${ }^{25)}$. As reported previously ${ }^{25}$, no significant differences in the XANES spectrum (pre-edge peaks and edge) from that in 4 were observed after addition of MAO, suggesting that the oxidation state of $\mathbf{4}$ was preserved after addition of MAO. These results agreed well with both the NMR and the ESR spectra of the toluene solution ${ }^{25)}$.

In contrast, as shown in Fig. 3, remarkable changes in the XANES (pre-edge and edge region) spectrum was observed when 4 was treated with 10 equiv. of $\mathrm{Al}^{i} \mathrm{Bu}_{3}{ }^{25)}$, and the spectrum did not change upon further addition of NBE (10 equiv.). These results clearly suggest that species formed by treatment of $\mathbf{4}$ with $\mathrm{Al}^{i} \mathrm{Bu}_{3}$ are the active species in this catalysis. Moreover, formation of different active species with different oxidation states occurs in the solution containing $\mathbf{4}$ after addition of $\mathrm{MAO}$ and $\mathrm{Al}^{i} \mathrm{Bu}_{3}$.

Moreover, the intensity of the edge peak slightly increased with the decrease in the intensity of the preedge peak after addition of 100 equiv. of $\mathrm{Al}^{i} \mathrm{Bu}_{3}$, whereas no significant changes in the pre-edge peak position and the edge peak were observed by varying the $\mathrm{Al} / \mathrm{V}$ molar ratio. Apparent decreases in the intensity of pre-edge peak upon addition of $\mathrm{Al}^{i} \mathrm{Bu}_{3}$ clearly suggests certain structural changes in the distorted tetrahedral geometry around vanadium caused by reaction with $\mathrm{Al}$ alkyls to form another species by reduction ${ }^{25), 39)}$, and the result suggests that the difference caused by higher percentage of catalytically active species for ethylene (co)polymerization $^{24), 25)}$. Based on our previous NMR and ESR study of the catalyst solution consisting of $\mathbf{4}$ and $\mathrm{Al}^{i} \mathrm{Bu}_{3}$ [and the low energy shift in the edge peak compared to the related vanadium(IV) complex, Fig. 3 $]^{25), 34)}$, presumably certain vanadium(III) species were generated by reduction of $\mathbf{4}$ after addition of $\mathrm{Al}^{i} \mathrm{Bu}_{3}$. The results thus clearly and strongly suggest that species formed from 4 by addition of $\mathrm{Al}^{i} \mathrm{Bu}_{3}$ preserve the basic structure irrespective of $\mathrm{Al} / \mathrm{V}$ molar ratios as well as addition of NBE. We think that this is important information for the better understanding of the catalysis.

The present study investigated solution phase $\mathrm{V}$ K-edge XANES spectra (in toluene at $25^{\circ} \mathrm{C}, 5.46 \mathrm{keV}$ ) of a series of 4 coordinate (imido)vanadium(V) dichloride complexes containing monodentate anionic ancillary donor ligands as follows, $\mathrm{V}(\mathrm{NAr}) \mathrm{Cl}_{2}(\mathrm{~L})$ [ $\mathrm{Ar}=$ 2,6- $\mathrm{Me}_{2} \mathrm{C}_{6} \mathrm{H}_{3} ; \mathrm{L}=\mathrm{OAr}$ (1a), O-2,6- $\mathrm{Ph}_{2} \mathrm{C}_{6} \mathrm{H}_{3}$ (1), $\mathrm{N}=$ $\left.\mathrm{C}^{t} \mathrm{Bu}_{2}(2), 1,3{ }^{t} \mathrm{Bu}_{2}(\mathrm{CHN})_{2} \mathrm{C}=\mathrm{N}(3), \mathrm{WCA}-\mathrm{NHC}(\mathbf{4})\right]$ and $\mathrm{V}(\mathrm{NAd}) \mathrm{Cl}_{2}(\mathrm{OAr})(\mathbf{1 c})$. Although slight differences in the pre-edge peaks were observed, all the spectra showed a pre-edge (5466.4-5467.4 eV) peak in addition to a shoulder-edge (5477.7-5478.6 eV) peak, which is characteristic of the presence of $\mathrm{V}-\mathrm{Cl}$ bonds $^{34)}$, and no significant differences were observed irrespective of the anionic ancillary donor ligands. The spectra (preedge, shoulder-edge, and edge peaks) for 1a,b did not change after addition of MAO and NBE, clearly suggesting that the oxidation state did not change as observed previously ${ }^{25), 38), 39)}$. In contrast, decrease in the pre-edge peak along with low energy shift of the edge peak in the spectrum were observed when $\mathbf{4}$ was treated with 10 equiv. of $\mathrm{Al}^{i} \mathrm{Bu}_{3}$, and the spectrum did not change with addition of NBE; no remarkable changes in the pre-edge and edge peak were observed after further addition of $\mathrm{Al}^{i} \mathrm{Bu}_{3}$. The results suggest that generated vanadium(III) species are active in this catalysis under these conditions. We believe that the information should be important for the basic understanding of the catalysis mechanism, although more information is needed concerning the active vanadium(III) species through careful FT-EXAFS analysis of the catalyst solutions.

\section{Experimental Section}

General Procedure. All experiments were carried out under a nitrogen atmosphere in a Vacuum Atmospheres drybox. Anhydrous grade toluene 
(Kanto Chemical Co., Inc.) was transferred into a bottle containing molecular sieves (a mixture of $3 \mathrm{~A} 1 / 16,4 \mathrm{~A}$ $1 / 8$, and $13 \mathrm{X} 1 / 16$ ) in the drybox under a nitrogen stream, and was passed through an alumina short column under a $\mathrm{N}_{2}$ stream prior to use. $\mathrm{V}(\mathrm{NAr}) \mathrm{Cl}_{2}(\mathrm{~L})$ $\left[\mathrm{Ar}=2,6-\mathrm{Me}_{2} \mathrm{C}_{6} \mathrm{H}_{3} ; \mathrm{L}=\mathrm{OAr}(\mathbf{1 a})^{15)}, \mathrm{O}-2,6-\mathrm{Ph}_{2} \mathrm{C}_{6} \mathrm{H}_{3}\right.$ $(\mathbf{1 b})^{15)}, \mathrm{N}=\mathrm{C}^{t} \mathrm{Bu}_{2}(2)^{50)}, 1,3-{ }^{t} \mathrm{Bu}_{2}(\mathrm{CHN})_{2} \mathrm{C}=\mathrm{N}(\mathbf{3})^{21)}$, WCA-NHC (4) ${ }^{24)}$ and $\mathrm{V}(\mathrm{NAd}) \mathrm{Cl}_{2}(\mathrm{OAr})(\mathbf{1 c})^{20)}$ were prepared according to published methods. $\mathrm{Al}^{i} \mathrm{Bu}_{3}$ was purchased from Kanto Chemical Co., Inc., and polymerization grade ethylene (purity $>99.9 \%$, Sumitomo Seika Co., Ltd.) was used as received. Toluene and $\mathrm{AlMe}_{3}$ in the commercially available methylaluminoxane [TMAO, $9.5 \mathrm{wt} \%$ (Al) toluene solution, Tosoh Finechem Corp.] were removed under reduced pressure (at ca. $50{ }^{\circ} \mathrm{C}$ for removing toluene, $\mathrm{AlMe}_{3}$, and then heated at $>100{ }^{\circ} \mathrm{C}$ for $1 \mathrm{~h}$ for completion) in the drybox to give white solids ${ }^{14) \sim 21)}$.

Analysis of Catalyst Solution by Solution-phase X-ray Absorption Spectroscopy. V K-edge X-ray absorption fine structure (XAFS) measurements were carried out using the BL01B1 beam line at the SPring- 8 facility of the Japan Synchrotron Radiation Research Institute (proposal nos. 2016A1455, 2016B1509, 2017A1315). The measurements were conducted at room temperature $\left(25^{\circ} \mathrm{C}\right)$. A Si (111) two-crystal monochromator was used for the incident beam. V K-edge XAFS spectra of V complex samples (prepared as toluene solution, $50 \mu \mathrm{mol} / \mathrm{mL}$ ) were recorded in the fluorescence mode using an ionization chamber as the $I_{0}$ detector and 19 solid state detectors as the $I$ detector. The X-ray energy was calibrated using $\mathrm{V}_{2} \mathrm{O}_{5}$. Data analysis was performed with the REX2000 Ver. 2.5.9 software package (Rigaku Corp.). The XANES data was analyzed by removing the atomic absorption background using a cubic spline from the $\chi$ spectra and normalization of them to the edge height.

\section{Acknowledgment}

This project was partly supported by Grant-in-Aid for Scientific Research on Innovative Areas ("3D Active-Site Science,” No. 26105003) from the Ministry of Education, Culture, Sports, Science and Technology (MEXT), Japan, and Grant-in-Aid for Scientific Research (B) from the Japan Society for the Promotion of Science (JSPS, No. 15H03812). Synchrotron XAS analysis was performed at SPring-8 beam lines of BL01B1 with the approval of JASRI (2016A1455, 2016B1509, 2017A1315). The authors would also express their heartfelt thanks to Prof. K. Jitsukawa and Prof. K. Kaneda (Osaka University) for their big supports for collaboration of XAFS analysis at SPring-8. K. N. expresses his thanks to Dr. S. Sueki, Mr. H. Harakawa, M. Kuboki (Tokyo Metropolitan Univ., TMU) for helping measurement of synchrotron XAFS analysis, and Prof. A. Inagaki and Prof. S. Komiya
(TMU) for discussions.

\section{References}

1) Selected recent reviews/accounts, refs. 1-10, see: "Orgaometallic Reactions and Polymerization," ed. by Osakada, K., The Lecture Notes in Chemistry 85, SpringerVerlag, Berlin (2014).

2) Mason, A. F., Coates, G. W., "Macromolecular Engineering," eds. by Matyjaszewski, K., Gnanou, Y., Leibler, L., WileyVCH, Weinheim, Germany (2007), 1, p. 217.

3) Metal-catalysed Polymerisation (special issue), eds. by Milani, B., Claver, C., Dalton Trans., 38, 8769 (2009).

4) Nomura, K., Liu, J., Padmanabhan, S., Kitiyanan, B., J. Mol. Catal. A: Chem., 267, 1 (2007).

5) Nomura, K., Dalton Trans., 38, 8811 (2009).

6) Makio, H., Terao, H., Iwashita, A., Fujita, T., Chem. Rev., 111, 2363 (2011).

7) Nomura, K., Zhang, S., Chem. Rev., 111, 2342 (2011).

8) Delferro, M., Marks, T. J., Chem. Rev., 111, 2450 (2011).

9) McInnis, J. P., Delferro, M., Marks, T. J., Acc. Chem. Res., 47, 2545 (2014).

10) Valente, A., Mortreux, A., Visseaux, M., Zinck, P., Chem. Rev., 113, 3836 (2013).

11) For selected reviews (vanadium catalysts) ${ }^{7)}$, refs. 11-14, see: Hagen, H., Boersma, J., van Koten, G., Chem. Soc. Rev., 31, 357 (2002).

12) Gambarotta, S., Coord. Chem. Rev., 237, 229 (2003).

13) Redshaw, C., Dalton Trans., 39, 5595 (2010).

14) Nomura, K., Hou, X., "Handbook of Transition Metal Polymerization Catalysts," 2nd Ed., ed. by Ray Hoff, John Wiley \& Sons Inc, Hoboken, NJ, USA (2018), pp.313-338.

15) Nomura, K., Sagara, A., Imanishi, Y., Macromolecules, 35, 1583 (2002).

16) Wang, W., Nomura, K., Macromolecules, 38, 5905 (2005).

17) Wang, W., Nomura, K., Adv. Synth. Catal., 348, 743 (2006).

18) Diteepeng, N., Tang, X.-Y., Hou, X., Li, Y.-S., Phomphrai, K., Nomura, K., Dalton Trans., 44, 12273 (2015).

19) Nomura, K., Wang, W., Yamada, J., Stud. Surf. Sci. Catal., 161, 123 (2006).

20) Zhang, W., Nomura, K., Inorg. Chem., 47, 6482 (2008).

21) Nomura, K., Bahuleyan, B. K., Zhang, S., Sharma, P. M. V., Katao, S., Igarashi, A., Inagaki, A., Tamm, M., Inorg. Chem., 53, 607 (2014)

22) Kolychev, E. L., Theuergarten, E., Tamm, M., Top. Curr. Chem., 334, 121 (2013).

23) Nasr, A., Winkler, A., Tamm, M., Coord. Rev., 316, 68 (2016).

24) Igarashi, A., Kolychev, E. L., Tamm, M., Nomura, K., Organometallics, 35, 1778 (2016).

25) Nagai, G., Mitsudome, T., Tsutsumi, K., Sueki, S., Ina, T., Tamm, M., Nomura, K., J. Jpn. Petrol. Inst., 60, (5), 256 (2017).

26) Thomas, J. M., Sankar, G., J. Synch. Rad., 8, 55 (2001).

27) Meitzner, G., "In-Situ Spectroscopy in Heterogeneous Catalysis," ed. by Haw, J. F., Wiley-VCH, Weinheim, Germany (2002).

28) Dent, A. J., Top. Catal., 18, 27 (2002).

29) Thomas, J. M., Catlow, C. R. A., Sankar, G., Chem. Commun., 24, 2921 (2002).

30) Koningsberger, D. C., Ramaker, D. E., "Handbook of Heterogeneous Catalysis," 2nd Ed., eds. by Ert1, G., Knözinger, H., Schüth, F., Weitkamp, J., Wiley-VCH, Weinheim, Germany (2008).

31) Bare, S. R., Ressler, T., Adv. Catal, 52, 339 (2009).

32) "XAFS Techniques for Catalysts, Nanomaterials, and Surfaces," eds. by Iwasawa, Y., Asakura, K., Tada, M., 
Springer, Switzerland (2017).

33) Linehan, J. C., Balasubramanian, M., Fulton, J. L., "XAFS Techniques for Catalysts, Nanomaterials, and Surfaces," eds. by Iwasawa, Y., Asakura, K., Tada, M., Springer, Switzerland (2017), p. 431.

34) Nomura, K., Mitsudome, T., Tsutsumi, K., Yamazoe, S., J. Phys. Soc. Jpn., 87, 061014 (2018).

35) Bartlett, S. A., Moulin, J., Tromp, M., Reid, G., Dent, A. J., Cibin, G., McGuinness, D. S., Evans, J., ACS Catal., 4, 4201 (2014).

36) Tromp, M., Phil. Trans. R. Soc. A, 373 : 20130152, DOI: doi. org/10.1098/rsta.2013.0152.

37) Takaya, H., Nakajima, S., Nakagawa, N., Isozaki, K., Iwamoto, T., Imayoshi, R., Gower, N. J., Adak, L., Hatakeyama, T., Honma, T., Takagaki, M., Sunada, Y., Nagashima, H., Hashizume, D., Takahashi, O., Nakamura, M., Bull. Chem. Soc. Jpn., 88, 410 (2015).

38) Nomura, K., Mitsudome, T., Igarashi, A., Nagai, G., Tsutsumi, K., Ina, T., Omiya, T., Takaya, H., Yamazoe, S., Organometallics, 36, 530 (2017).

39) Nomura, K., Oshima, M., Mitsudome, T., Harakawa, H., Hao, P., Tsutsumi, K., Nagai, G., Ina, T., Takaya, H., Sun, W.-H., Yamazoe, S., ACS Omega, 2, 8660 (2017).

40) "Understanding Organometallic Reaction Mechanisms and Catalysis," ed. by Ananikov, V. P., Wiley-VCH, Weinheim, Germany (2015).

41) NMR, "Organometallic Chemistry," ed. by Pregosin, P. S., Wiley-VCH, Weinheim, Germany (2012).
42) "Application of EPR and NMR Spectroscopy in Homogeneous Catalysis," eds. by Talsi, E., Bryliakov, K., CRC Press, Boca Raton, USA (2017).

43) Goswami, M., Chirila, A., Rebreyend, C., de Bruin, B., Top Catal., 58, 719 (2015).

44) The solution XANES spectra of (arylimido)vanadium dichloride complexes containing ketimide ligand $(2 \text { in Scheme } 1)^{34)}$, and WCA-NHC ligand $(\mathbf{4})^{25)}$ were shown in the previous report.

45) For example (account), Yamamoto, T., Adv. X-Ray. Chem. Anal., Japan, 38, 45 (2007). The transition of a $1 \mathrm{~s}$ electron to $3 \mathrm{~d}$ orbital gives weak pre-edge peaks due to the electric quadrupole transition for any symmetries. An intense pre-edge peak is assigned to an electric dipole transition to p-character in the d-p hybridized orbital, and the mixing of a metal $4 p$ orbital with the $3 \mathrm{~d}$ orbital strongly depends on the coordination symmetry. Related references, Srivastava, U. C., Higam, H. L., Coord. Chem. Rev., 9, 275 (1973). References cited therein.

46) Yamamoto, T., X-Ray Spectrom., 37, 572 (2008).

47) Wong, J., Lytle, F. W., Messmer, R. P., Maylotte, D. H., Phys. Rev. B., 30, 5596 (1984).

48) Asakura, H., Shishido, T., Yamazoe, S., Teramura, K., Tanaka, T., J. Phys. Chem. C, 115, 23653 (2011).

49) It was confirmed (in reference 38 ) that the curve-fitting of XANES spectrum of $\mathrm{V}(\mathrm{NAd}) \mathrm{Cl}_{3}$ is good agreement with that estimated by DFT calculation.

50) Yamada, J., Fujiki, M., Nomura, K., Organometallics, 24, 2248 (2005).

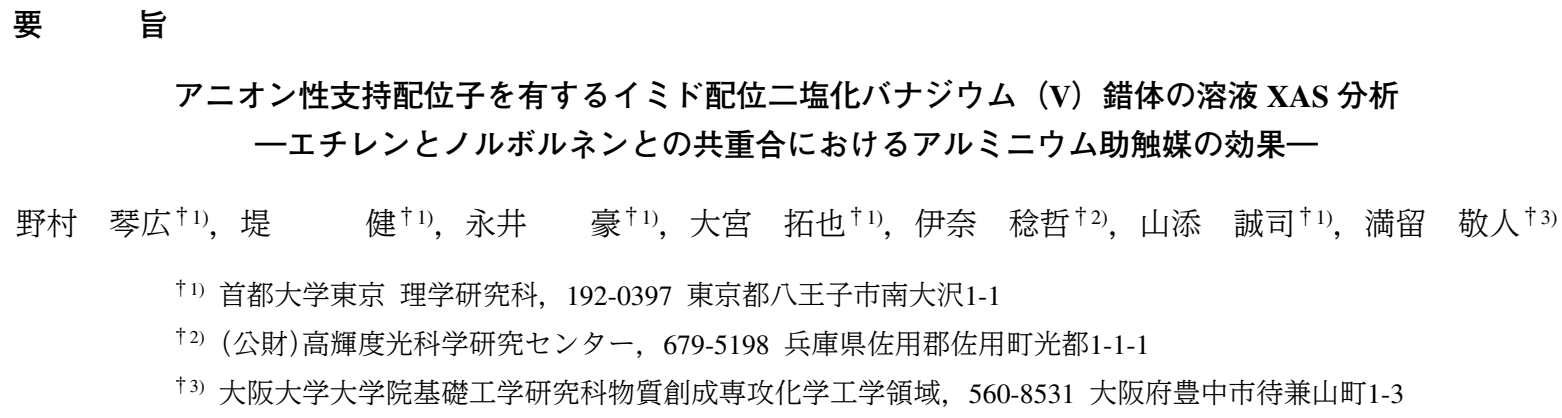

単座アニオン性支持配位子を有する4配位型のイミド配位バ ナジウムジクロリド錯体, $\mathrm{V}(\mathrm{NAr}) \mathrm{Cl}_{2}(\mathrm{~L})\left[\mathrm{Ar}=2,6-\mathrm{Me}_{2} \mathrm{C}_{6} \mathrm{H}_{3} ; \mathrm{L}\right.$ $=\mathrm{OAr}, \mathrm{O}-2,6-\mathrm{Ph}_{2} \mathrm{C}_{6} \mathrm{H}_{3}, \mathrm{~N}=\mathrm{C}^{t} \mathrm{Bu}_{2}, 1,3-{ }^{t} \mathrm{Bu}_{2}(\mathrm{CHN})_{2} \mathrm{C}=\mathrm{N}$, WCA$\mathrm{NHC}$ ( $N$-heterocyclic carbenes with a weakly coordinating borate moiety) および $\mathrm{V}(\mathrm{NAd}) \mathrm{Cl}_{2}(\mathrm{OAr})(\mathrm{Ad}=1$-adamantyl), のトルエン 溶液の XANES スペクトルにより，バナジウム原子周辺の局所 構造に対する配位子および配位子上の置換基効果を検討した。 バナジウム原子周辺のゆがんだ 4 配位テトラヘドラル構造を有 するいずれの錯体においてもプレエッジピークの位置に大きな 違いは見られず，バナジウム-塩素結合に帰属される shoulderedge ピークが観察された。また，(エチレンノノルホルネン共
重合に活性を有する) フェノキシ配位錯体に MAO やノルボル ネンを添加してもスペクトルに大きな変化は見られないことか ら，この触媒による重合は価数変化を伴わずに活性種が生成す ることが示唆された。一方, $\mathrm{V}\left(\mathrm{N}-2,6-\mathrm{Me}_{2} \mathrm{C}_{6} \mathrm{H}_{3}\right) \mathrm{Cl}_{2}$ (WCA-NHC) 錯体に $\mathrm{Al}^{i} \mathrm{Bu}_{3}$ 助触媒を添加すると顕著な変化（プレエッジピー ク強度の減少とエッジ領域の低エネルギーシフト)が観察され, 3 価種の生成が示唆された。このスペクトルは, $\mathrm{Al}^{i} \mathrm{Bu}_{3}$ の添加 量の増加でわずかにプレエッジピークの強度に変化が観察され るもののノルボルネンの添加による変化は見られないことか ら, いったん生成した還元種（3価バナジウム種）が直接触媒 反応に寄与する可能性が強く示唆された。 